\title{
PENGARUH KUALITAS KEBERAGAMAAN ORANG TUA TERHADAP MOTIVASI BELAJAR PAI SISWA
}

\author{
Iis Isnawati \\ Jurusan Pendidikan Agama Islam \\ Fakultas Tarbiyah dan Keguruan \\ UIN Sunan Gunung Djati Bandung
}

\begin{abstract}
The purpose of this study was to find out: 1) The quality of religious parents, 2) Motivation of student learning, and 3) The influence of the quality of parents' religiosity on the motivation to learn Islamic Education in class X Majalengka State Islamic Senior High School 1. The data collection technique is by observation, interview, and questionnaire. The analytical tool used is a partial analysis approach that produces variable $X$ with normal distribution, indicators of knowledge variables $X$ are abnormally distributed and $Y$ variables are normally distributed, then this correlation uses the product moment correlation formula and rank correlation. The results of the study concluded: 1) The reality of the variable $X$ an average of 3.45 which is interpreted to the sufficient category with normal distributed data, as evidenced by the price of $x^{2}$ count $2.74<x^{2}$ table 9.488. 2) Y variable reality on average is 2.69 which is interpreted to a sufficient category with normal distribution data, which is proven because the price of $x^{2}$ count is $4.19<x^{2}$ table 9.488. 3) Influence between variables $X$ and $Y$ variables obtained by $R x y=0.38$, which is a low correlation category. And the significance level obtained is tcount of 2.47 and ttable of 2.024 with a significance level of 5\%, so that tcount> $t$ table, that is, there is a significant influence between variables $X$ and $Y$. Therefore the proposed hypothesis is stated: Ha is accepted and Ho is rejected. Then the magnitude of the influence obtained $8 \%$ this shows there are still $92 \%$ of other factors that influence the motivation to learn PAI students.
\end{abstract}

Keywords: Religion, Motivation

\begin{abstract}
Abstrak :Tujuan dari penelitian ini adalah untuk mengetahui: 1)Kualitas keberagamaan orang tua, 2)Motivasi belajar siswa, dan 3)Pengaruh kualitas keberagamaan orang tua terhadap motivasi belajar Pendidikan Agama Islam pada siswa kelas X Madrasah Aliyah Negeri 1 Majalengka. Teknik pengumpulan datanya dengan observasi, wawancara, dan angket. Alat analisis yang digunakan adalah pendekatan analisis parsial yang menghasilkan variabel $\mathrm{X}$ berdistribusi normal, indikator pengetahuan variabel X berdisribusi tidak normal dan variabel Y berdistribusi normal, maka korelasi ini menggunakan rumus korelasi product moment dan korelasi rank. Hasil penelitian diperoleh kesimpulan: 1) Realitas variabel X rata-rata sebesar 3,45 yang ditafsirkan kepada kategori cukup dengan data berdistribusi normal, terbukti karena harga $x^{2}$ hitung 2,74 $<x^{2}$ tabel 9,488. 2) Realitas variabel Y rata-rata sebesar 2,69 yang ditafsirkan kepada kategori cukup dengan data berdistribusi normal, yang terbukti karena harga ${ }_{\mathrm{x}}^{2}$ hitung $4,19<x^{2}$ tabel 9,488. 3) Pengaruh antara variabel X dengan variabel Y diperoleh $\mathrm{Rxy}=0,38$ yaitu kategori korelasi rendah. Dan taraf signifikasi diperoleh $t_{\text {hitung }}$ sebesar 2,47 dan $t_{\text {tabel }}$ sebesar 2,024 dengan taraf signifikasi $5 \%$, sehingga $t_{\text {hitung }}>t_{\text {tabel }}$, yakni terdapat pengaruh yang signifikan antara variabel $\mathrm{X}$ dan variabel Y. Oleh karena itu hipotesis yang diajukan dinyatakan: Ha diterima dan Ho ditolak. Kemudian besarnya pengaruh diperoleh $8 \%$ hal ini menunjukkan masih ada $92 \%$ faktor lain yang mempengaruhi motivasi belajar PAI siswa.
\end{abstract}

Kata kunci: Keberagamaan, Motivasi

\section{PENDAHULUAN}

Manusia dilahirkan dalam keadaan tidak mengetahui sesuatu apapun, namun ia telah memiliki kemampuan bawaan yang bersifat laten. Kemampuan bawaan ini memerlukan pengembangan melalui bimbingan dan pemeliharaan yang mantap, terlebih lagi pada usia dini. (Jalaludin, 2012: 63)

Sebagai makhluk ciptaan Tuhan, sebenarnya potensi agama sudah ada pada setiap manusia sejak ia dilahirkan. Potensi ini berupa dorongan untuk mengabdi kepada 
Sang Pencipta. Dalam terminologi Islam, dorongan ini dikenal dengan bidayat alDiniyat, yang mana dorongan ini berupa benih-benih keberagamaan yang dianugerahkan Tuhan kepada manusia. Dengan adanya potensi bawaan ini manusia pada hakikatnya adalah makhluk beragama. (Jalaludin, 2012: 67)

Hamzah B. Uno memaparkan bahwa setiap individu memiliki kondisi internal, di mana kondisi internal tersebut turut berperan dalam aktivitas dirinya sehari-hari. Salah satu dari kondisi internal tersebut adalah 'motivasi'. Menurutnya, motivasi adalah dorongan dasar yang menggerakkan seseorang bertingkah laku. Dorongan ini berada pada diri seseorang yang menggerakkan untuk melakukan sesuatu yang sesuai dengan dorongan dalam dirinya. Oleh karena, perbuatan seseorang yang didasarkan atas motivasi tertentu mengandung tema sesuai dengan motivasi yang mendasarinya. (Uno, 2016: 1)

Merujuk pada penjelasan bahwa manusia telah memiliki potensi keberagamaan sejak ia dilahirkan, yang mana potensi tersebut berupa dorongan untuk mengabdi kepada Sang Pencipta. Bila penjelasan tersebut dikaitkan dengan pengertian motivasi menurut Hamzah B. Uno yang mana menurutnya motivasi dapat diartikan sebagai dorongan dasar yang menggerakkan seseorang bertingkah laku. Dari penjelasan di atas, dapat ditarik benang merah bahwa potensi keberagamaan yang dimiliki manusia sejak lahir tersebut dapat juga diartikan sebagai motivasi bawaan yang sudah dimiliki manusia sejak ia dilahirkan.

Untuk mengembangkan potensi atau motivasi keberagamaan tersebut diperlukan bimbingan serta pemeliharaan yang baik, terlebih lagi pada usia dini. Bimbingan dan pemeliharaan tersebut dapat dilakukan melalui pendidikan. Baik pendidikan formal, non formal, maupun informal. Pendidikan formal yang merupakan pendidikan sekolah yang diperoleh secara teratur, sistematis, bertingkat, dan mengikuti syarat-syarat yang jelas. Adapun pendidikan non formal merupakan jalur pendidikan di luar pendidikan formal yang dapat dilaksanakan secara terstruktur dan berjenjang. Sedangkan pendidikan informal merupakan jalur pendidikan keluarga dan lingkungan yang berbentuk kegiatan belajar secara mandiri.

Ketiga pendidikan tersebut, pendidikan pertama yang di dapat anak adalah pendidikan keluarga terutama orang tua. Karena orang tua merupakan pendidik utama dan pertama bagi anak-anak mereka. (Mahmud, 2012: 135) Dengan demikian, bentuk pertama pendidikan terdapat dalam keluarga yakni para orang tua. (Daradjat, 2008: 35)

Seperti yang telah kita ketahui bahwasannya Allah Swt., telah mengutus para nabi dan rasul sebagai pemberi pengajaran, dan suri tauladan. Lalu berikutnya risalah kerasulan ini diturunkan kepada para ulama. Namun, tugas utamanya dititikberatkan kepada kedua orang tua. Dipesankan rasul bahwa bayi dilahirkan dalam keadaan fitrah, yaitu dorongan untuk mengabdi kepada Penciptanya. Namun, benar tidaknya cara dan bentuk pengabdian yang dilakukannya, sepenuhnya tergantung dari kedua orang tua masing-masing. (Jalaludin, 2012: 69)

Pendidikan anak di sekolah pada dasarnya dipengaruhi oleh keterlibatan orang tua. Sebab orang tua lebih sering berhubungan langsung dengan anak. William J. Goode 
mengemukakan bahwa keberhasilan atau prestasi yang dicapai siswa dalam pendidikannya sesungguhnya tidak hanya memperlihatkan mutu dari institusi pendidikan saja. Tetapi memperlihatkan juga keberhasilan keluarga dalam memberikan anak-anak mereka persiapan yang baik untuk pendidikan yang dijalani. (Mahmud, 2012: 135) Apabila di rumah sudah diberikan pendidikan terutama pendidikan agama dengan baik, maka pendidikan agama di sekolahpun akan berlangsung baik, begitupun sebaliknya.

Madrasah Aliyah Negeri (MAN) merupakan sekolah yang berbasis Madrasah yang otomatis intensitas pembelajaran Agama Islam di madrasah lebih banyak dibandingkan di sekolah umum lainnya. Hal tersebut tidak membuat siswa memiliki motivasi yang baik dalam hal belajar pendidikan Agama Islam. Berdasarkan informasi yang diperoleh dari salah satu guru PAI bahwa dari pihak sekolah beserta para guru sudah melakukan upaya untuk meningkatkan motivasi belajar siswa, terutama dalam meningkatkan motivasi belajar Agama Islam. Guru telah melakukan upaya dari mulai memotivasi siswa secara verbal yaitu melalui bimbingan dan nasihat, serta melalui bentuk nilai tertulis. Selain itu, pihak sekolah juga mengadakan fasilitas berupa boarding school untuk memotivasi siswa dalam belajar ilmu agama sekaligus menambah wawasan ilmu agama serta untuk memudahkan siswa yang jarak antara rumah dengan sekolahnya jauh. Akan tetapi, hal tersebut tidak memperlihatkan hasil yang cukup baik. Sebab pada saat proses pembelajaran berlangsung sebagian siswa kurang memperhatikan pembelajaran, diantara mereka ada yang sibuk berbincang dengan teman sebangkunya, sibuk mengerjakan tugas mata pelajaran lain, ataupun sibuk dengan handphone-nya. Serta adanya boarding school juga tidak membuat siswa terdorong untuk tinggal di boarding untuk mempelajari serta memperdalam ilmu agama. Hal ini dilihat dari sedikitnya siswa kelas X yang tinggal di boarding. Sebenarnya banyak faktor yang dapat mempengaruhi motivasi belajar salah satunya dorongan dari orang tua, termasuk dari bagaimana kualitas keberagamaan orang tua. Dalam hal ini, nilai-nilai keberagamaan yang terdapat dalam diri orang tua dan pendidikan yang diberikan orang tua akan mempengaruhi motivasi anak untuk mempelajari Agama Islam di sekolah maupun di mana saja. Maka dari itu, perlu untuk mengetahui bagaimana motivasi atau dorongan dari orang tua bagi siswa untuk belajar, baik itu belajar di kelas atau lingkungan sekolah ataupun diluar sekolah.

Oleh karena itu, rumusan masalah dari penelitian ini adalah 1) Bagaimana kualitas keberagamaan orang tua siswa kelas X Madrasah Aliyah Negeri 1 Majalengka? 2) Bagaimana motivasi belajar pendidikan Agama Islam pada siswa kelas X Madrasah Aliyah Negeri 1 Majalengka? 3) Bagaimana pengaruh kualitas keberagamaan orang tua terhadap motivasi belajar Pendidikan Agama Islam pada siswa kelas X Madrasah Aliyah Negeri 1 Majalengka?

Penelitian ini juga memiliki tujuan yakni untuk mengetahui 1) Kualitas keberagamaan orang tua siswa kelas X Madrasah Aliyah Negeri 1 Majalengka; 2) Motivasi belajar pendidikan Agama Islam pada siswa kelas X Madrasah Aliyah Negeri 
1 Majalengka; 3) Pengaruh kualitas keberagamaan orang tua terhadap motivasi belajar agama pada siswa kelas X Madrasah Aliyah Negeri 1 Majalengka.

Adapun bagan kerangka pemikiran dari penelitian ini yaitu sebagai berikut :

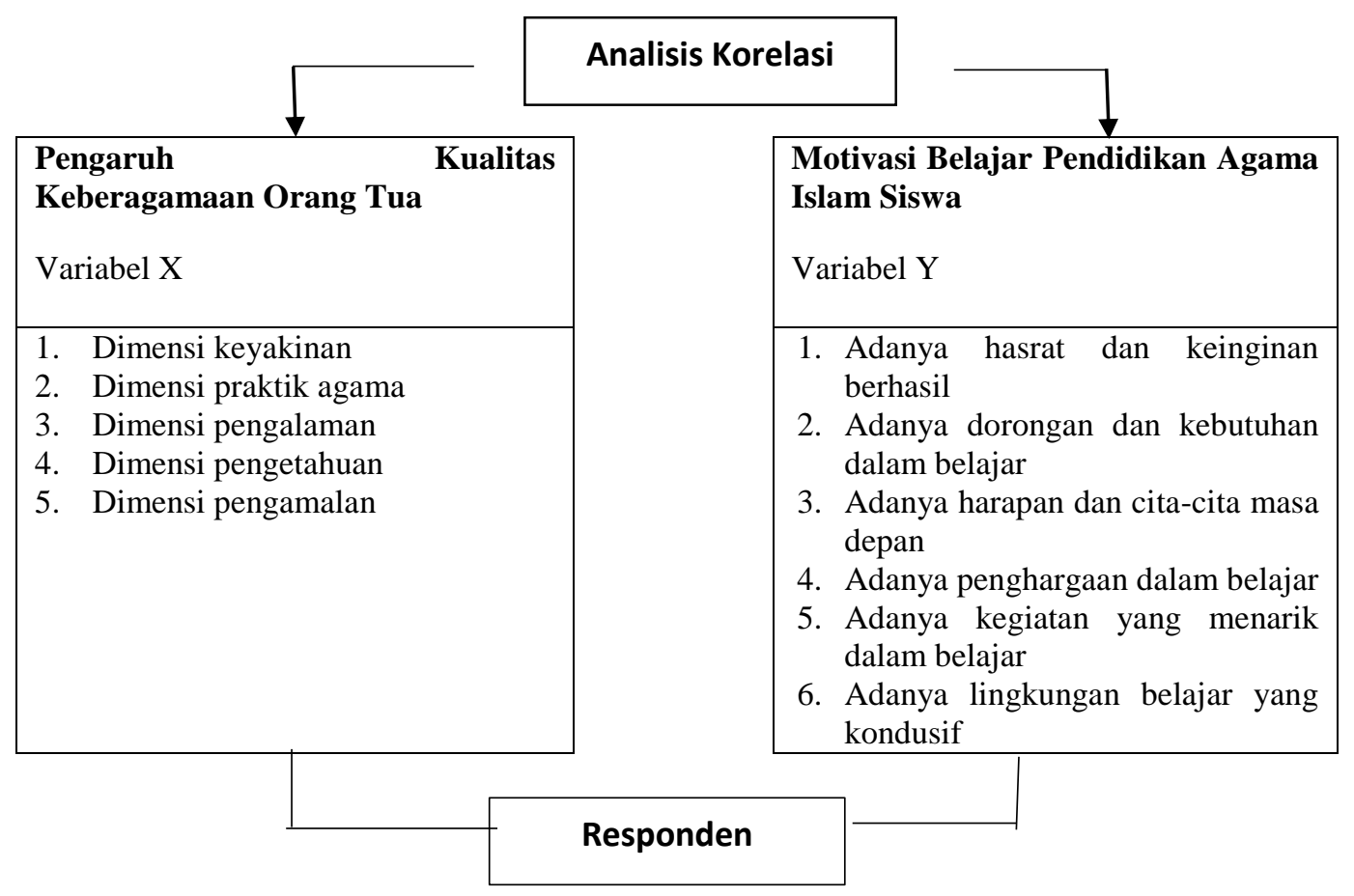

Bagan 1.1

\section{Bagan Kerangka Pemikiran}

Hipotesis dari penelitian ini adalah "terdapat pengaruh antara kualitas keberagamaan orang tua terhadap motivasi belajar Pendidikan Agama Islam siswa".

\section{Pengertian Keberagamaan}

Kata agama dalam bahasa Indonesia berarti sama dengan "diri” dalam bahasa Arab dan Semit, atau dalam bahasa Inggris "religion". (Didiek Ahmad Supadie, 2012: 35) Kata 'religi' itu sendiri berasal dari bahasa Latin 'ereligio' yang akar katanya adalah 'religare' dan berarti 'mengikat'. Maksudnya adalah bahwa di dalam religi (agama) pada umumnya terdapat aturan-aturan dan kewajiban-kewajiban yang harus dilaksanakan, yang semuanya itu berfungsi untuk mengikat dan mengutuhkan diri seseorang atau sekelompok orang dalam hubungannya terhadap Tuhan, sesama manusia serta alam sekitarnya. (Subandi, 2013: 87) Istilah "beragama" seperti disebut Lukman Ali dalam kamus bahasa Indonesia, mempunyai arti menganut (memeluk agama) taat kepada agama, beribadah. Pengertian "keagamaan" yaitu adalah yang berhubungan dengan agama. Sedangkan "keberagamaan" sendiri merupakan perilaku-perilaku beragama ataupun perwujudan atas keyakinan yang dimiliki seseorang. (Zainuddin, 2017) Anshori membedakan antara istilah religi atau agama dengan religiusitas (keberagamaan). Jika agama menunjuk pada aspek-aspek formal yang berkaitan dengan aturan dan kewajiban, maka religiusitas menunjuk kepada aspek religi yang telah dihayati oleh seseorang dalam hati. Pendapat tersebut senada dengan Dister yang mengartikan religiusitas 
sebagai keberagamaan karena adanya internalisasi agama ke dalam siri seseorang. Monks dkk. Mengartikan keberagamaan sebagai keterdekatan yang lebih tinggi dari manusia kepada Yang Maha Kuasa yang memberikan perasaan aman. Sementara Shihab menyatakan bahwa agama adalah hubungan antara makhluk dengan Khalik (Tuhan) yang berwujud iabadah yang dilakukan dalam sikap keseharian. Selanjutnya, Anshori memberikan arti agama secara detail, yakni agama sebagai suatu credo (tata keyakinan) atas adanya Yang Maha Mutlak dan suatu sistem norma (tata kaidah) yang mengatur hubungan manusia dengan sesama manusia dan dengan alam sekitarnya, sesuai dengan tata keimanan dan tata peribadatan tersebut. Menurut beberapa ahli yang di kemukakan Spink, di dalam diri manusia terdapat suatu insting atau naluri yang disebut religious instink, yaitu naluri untuk meyakini dan mengadakan penyembahan terhadap suatu kekuatan yang ada di luar diri manusia. Naluri inilah yang mendorong manusia melakukan kegiatan-kegiatan yang sifatnya religius. Selanjutnya, dikatakan bahwa beberapa ahli lain tidak menyebut secara langsung bahwa dorongan itu adalah instink religious, tetapi mereka berpendapat bahwa naluri atau dorongan untuk mencapai suatu keutuhan itulah yang merupakan akar dari religi. Pruyser mengemukakan bahwa manusia pada dasarnya adalah makhluk religius atau manusia merupakan makhluk yang berkembang menjadi religius. Jadi, pada dasarnya manusia merupakan makhluk yang beragama. (M. Nur Ghufron, 2012: 168) Agama dalam pengertian Glock \& Stark, adalah sistem, simbol, sistem keyakinan, sistem nilai, dan sistem perilaku yang terlembagakan, yang semuanya itu berpusat pada persoalan-persoalan yang dihayati sebagai yang paling maknawi (ultimate meaning). (Djamaludin Ancok, 2011: 76) Berdasarkan beberapa pengertian di atas, istilah keberagamaan dapat diartikan sebagai sebuah aktualisasi nilainilai keagamaan dalam kehidupan dengan perilaku taat beribadah serta memiliki hubungan yang baik dengan manusia serta makhluk hidup lainnya. Dalam pandangan Islam, potensi keberagamaan telah dimiliki sejak lahir, namun potensi tersebut tetap harus dikembangkan melalui pendidikan atau bimbingan. Indikator keberagamaan Menurut Glock \& Stark, ada lima dimensi keberagamaan, yaitu keyakinan (ideologis), dimensi peribadatan atau praktek agama (ritualistik), dimensi penghayatan (eksperiensial), dimensi pengamalan (konsekuensial), dimensi pengetahuan agama (intelektual).

\section{Pengertian Motivasi}

Winkels mengemukakan bahwa motif adalah adanya penggerak dalam diri seseorang untuk melakukan aktivitas-aktivitas tertentu demi mencapai suatu tujuan tertentu. Pengertian ini bermakna jika seseorang melihat suatu manfaat dan keuntungan yang akan diperoleh, maka ia akan berusaha keras untuk mencapai tujuan tersebut. (Eveline Siregar, 2014: 49) Wexley dan Yukl, motivasi adalah pemberian atau penimbulan motif. Dapat pula diartikan sebagai hal atau keadaan yang menjadi motif. Filrnore Sanford mengartikan motivasi sebagai suatu kondisi (kekuatan/dorongan) yang menggerakkan organisme (individu) untuk mencapai suatu tujuan atau beberapa tujuan dan tingkat tertentu. (Gunawan, 2012: 140) Belajar merupakan suatu kebutuhan manusia agar menjadi manusia dalam arti yang sesungguhnya. Seperti istilah yang dipakai oleh 
Ahmad Tafsir yaitu "memanusiakan manusia. Belajar merupakan suatu proses perubahan tingkah laku sebagai hasil dari interaksi dengan lingkungan. Belajar dalam pandangan Islam merupakan suatu keharusan yang dilakukan manusia dari sejak lahir hingga ia meninggal. Sedangkan motivasi belajar merupakan suatu dorongan baik yang berasal dari dalam diri siswa maupun dari luar yang memberi gerakan serta arah dalam kegiatan belajar hingga menimbulkan suatu hasil yakni perubahan tingkah laku ke arah yang lebih baik serta dapat mencapai tujuan sesuai yang dikehendaki. Untuk mendalami mengenai motivasi belajar peserta didik, Hamzah B. Uno mengemukakan bahwa indikator motivasi belajar dapat diklarifikasikan sebagai berikut: (1) Adanya hasrat dan keinginan berhasil; (2) Adanya dorongan dan kebutuhan dalam belajar; (3) Adanya harapan dan cita-cita masa depan; (4) Adanya penghargaan dalam belajar; (5) Adanya kegiatan yang menarik dalam belajar; (6) Adanya lingkungan belajar yang kondusif (Uno, 2016: 23)

\section{METODOLOGI PENELITIAN}

Secara umum penelitian ini akan dilaksanakan dengan menggunakan penelitian deskriptif korelasional, pendekatan penelitian yang digunakan dalam penelitian ini yaitu pendekatan penelitian kuantitatif yang merupakan suatu pendekatan yang secara primer menggunakan paradigma positivisme dalam mengembangkan ilmu pengetahuan, menggunakan strategi penelitian seperti eksperimen dan survei yang memerlukan data statistik. Pemikiran dalam penelitian ini yaitu menggunakan salah satu pemikiran dari pendekatan potivistik yakni mengenai sebab akibat dari dua variabel yang akan diteliti, jenis penelitian yang digunakan yaitu merupakan penelitian kuantitatif. Penelitian kuantitatif yang akan digunakan yaitu penelitian survei yang merupakan tipe penelitian dengan menggunakan kuesioner atau angket sebagai sumber data utama, sedangkan data teoritik diperoleh dari sumber serta literature yang ada hubungannya dengan judul skripsi untuk dijadikan sumber referensi. Sedangkan terkait data empirik akan diperoleh melalui observasi, penyebaran angket, wawancara, serta studi kepustakaan. Sumber yang digunakan dalam penelitian ini terdiri atas data primer dan data sekunder. Data primer diperoleh dari orang tua siswa, siswa dan juga beberapa pihak yang berkaitan. Sedangkan data sekunder diperoleh dari buku-buku, jurnal dan lainnya yang berhubungan dengan penelitian ini.

Penelitian ini dilaksanakan di MAN 1 Majalengka yang berlokasi di Desa Talaga Kulon Kec. Talaga Kab. Majalengka. Untuk waktu penelitian, studi pendahuluan dilakukan mulai Desember 2017, sedangkan untuk penelitian di mulai sejak di sahkannya proposal penelitian serta turunnya surat izin penelitian sampai dengan selesai.

Teknik pengumpulan data yang digunakan dalam penelitian ini yaitu observasi, angket, wawancara, dan studi kepustakaan. Observasi yang dilakukan yakni dengan melihat bagaimana proses pembelajaran berlangsung serta melihat hasil belajar siswa. Observasi juga dilakukan dalam rangka memperoleh data sekolah, keadaan MAN 1 Majalengka baik fisik (sarana dan prasarana), struktur organisasi, keadaan guru dan siswa. Untuk angket angket bertujuan untuk memperoleh data utama tentang kualitas keberagamaan orang tua dan motivasi belajar siswa. Angket ini berisikan pertanyaan 
yang berkaitan dengan indikator dari masalah yang akan diteliti dan yang menjadi responden dalam angket ini adalah sampel dari siswa kelas X MAN 1 Majalengka mengenai angket motivasi belajar serta orang tua siswa yang bersangkutan mengenai angket kualitas keberagamaan orang tua. Studi pustaka merupakan upaya untuk memperoleh teori atau informasi teoritik dari bahan bacaan yang berhubungan dengan penelitian yang dilakukan peneliti, baik melalui buku, jurnal, artikel ataupun informasi tambahan yang didapat dari website.

\section{HASIL KAJIAN DAN PEMBAHASAN}

Untuk mengetahui kualitas keberagamaan orang tua siswa, berdasarkan pada pokok yang diambil melalui angket yang memuat 24 item pertanyaan, yang disebarkan kepada 40 orang responden sebagai orang tua siswa sebagai salah satu responden dalam penelitian ini. Penyusunan angket tersebut mengacu pada lima indikator, yaitu : 1) Dimensi Keyakinan, 2) Dimensi Praktek, 3) Dimensi Konsekuensi, 4) Dimensi Pengalaman, 5) Dimensi Pengetahuan. Pada masing-masing indikator diajukan 1, 2, 3, 4 atau 5 item pertanyaan.

Penskoran dilakukan dengan menerapkan standar penilaian sebagai berikut : untuk pertanyaan positif, responden yang memilih altrenatif jawaban a, 4, untuk alternatif jawaban b, 3, untuk alternatif jawaban c, 2, untuk alternatif jawaban d, 1, dan untuk pertanyaan negatif sebaliknya. Sedangkan untuk indikator dimensi pengetahuan, setiap soal diberi bobot skor untuk masing-masing soal terhadap jawaban subjek yakni 1 untuk jawaban benar dan 0 untuk jawaban salah.

Untuk mengetahui variasi skor yang diperoleh responden, penulis menetapkan skala penilaian yang mengacu pada kriteria sebagai berikut :

$$
\begin{aligned}
& \text { Skor } 0,5-1,5=\text { Sangat Kurang } \\
& \text { Skor } 1,5-2,5=\text { Kurang } \\
& \text { Skor } 2,5-3,5=\text { Cukup } \\
& \text { Skor } 3,5-4,5=\text { Baik } \\
& \text { Skor } 4,5-5,5=\text { Sangat Baik }
\end{aligned}
$$

Untuk mengetahui variasi skor yang diperoleh responden pada indikator dimensi pengetahuan, penulis menetapkan kualifikasi skala 100, artinya nilai bergerak dari $0-$ 100 dengan kriteria sebagai berikut :

$$
\begin{aligned}
& 90-100=\text { Sangat Baik } \\
& 80-89=\text { Baik } \\
& 70-79=\text { Cukup } \\
& 60-69=\text { Sedang } \\
& 50-59=\text { Kurang } \\
& \leq \quad=\text { Sangat Kurang }
\end{aligned}
$$

Mengenai Kualitas Keberagamaan Orang Tua

1. Analisis Parsial Perindikator Variabel X

a) Dimensi keyakinan 
Pada indikator ini mengajukan 5 item pertanyaan yaitu: item no 1, 2, 3, 4, 5. Nilai rata-rata pada item no 1 dihasilkan dari $(29 x 4)+(10 \times 3)+(1 \times 1)=116+30+1=174$ : $40=3,67$. Nilai rata-rata pada item no 2 dihasilkan dari $(35 \times 4)+(5 \times 3)=140+15=155$ $: 40=3,87$. Nilai rata-rata pada item no 3 dihasilkan dari $(31 \times 4)+(9 \times 3)=124+27=$ $151: 40=3,77$. Nilai rata-rata pada item no 4 dihasilkan dari $(35 \times 4)+(5 \times 3)=140+15$ $=155: 40=3,87$. Nilai rata-rata pada item no 5 dihasilkan dari $(28 \times 4)+(10 \times 3)+(1 \times 2)$ $+(1 \times 1)=145+30+2+1=145: 40=3,62$.

Dari data tersebut, apabila kelima skor rata-rata setiap item dihitung rata-rata akhirnya, maka hasilnya $(3,67+3,87+3,77+3,87+3,62): 5=18,8: 5=3,76$. Dengan demikian, indikator dimensi keyakinan kualitas keberagamaan orang tua termasuk ke dalam kategori baik, karena berada pada interval 3,5 - 4,5.

b) Dimensi praktek

Pada indikator ini mengajukan 5 item pertanyaan yaitu: item no 6, 7, 8, 9, 10 . Nilai rata-rata pada item no 6 dihasilkan dari $(28 \times 4)+(10 \times 3)+(2 \times 2)=146+30+4=$ $146: 40=3,65$. Nilai rata-rata pada item no 7 dihasilkan dari $(35 \times 4)+(5 \times 3)=140+15$ $=155: 40=3,87$. Nilai rata-rata pada item no 8 dihasilkan dari $(24 \times 4)+(15 \times 3)+(1 \times 2)$ $=96+45+2=143: 40=3,57$. Nilai rata-rata pada item no 9 dihasilkan dari $(10 \times 4)+$ $(19 \times 3)+(11 \times 2)=40+57+22=119: 40=2,97$. Nilai rata-rata item no 10 dihasilkan dari $(40 \times 4)=160: 40=4$.

Dari data tersebut, apabila kelima skor rata-rata setiap item tersebut dihitung rata-rata akhirnya, maka hasilnya adalah $(3,65+3,87+3,57+2,97+4): 5=18,06: 5$ $=3,61$. Dengan demikian, indikator dimensi praktek kualitas keberagamaan orang tua termasuk ke dalam kategori baik, karena berada pada interval 3,5-4,5.

c) Dimensi Konsekuensi

Pada indikator ini mengajukan 4 item pertanyaan yaitu: item no 11, 12, $13,14$. Nilai rata-rata pad a item no 11 dihasilkan dari $(34 \times 4)+(6 \times 3)=154+18=154: 40=$ 3,85 . Nilai rata-rata pada item no 12 dihasilkan dari $(11 \times 4)+(25 \times 3)+(4 \times 2)=44+75$ $+8=127: 40=3,17$. Nilai rata-rata pada item no 13 dihasilkan dari $(17 \times 4)+(18 \times 3)+$ $(5 \times 2)=68+54+10=132: 40=3,3$. Nilai rata-rata pada item no 14 dihasilkan dari $(10 \times 4)+(12 \times 3)+(18 \times 2)=40+36+36=112: 40=2,8$.

Dari data tersebut, apabila kelima skor rata-rata setiap item tersebut dihitung rata-rata akhirnya, maka hasilnya adalah $(3,85+3,17+3,3+2,8): 4=13,12: 4=3,28$. Dengan demikian, indikator dimensi konsekuensi kualitas keberagamaan orang tua termasuk ke dalam kategori Cukup, karena berada pada interval 2,5 - 3,5.

d) Dimensi pengalaman

Pada indikator ini mengajukan 4 item pertanyaan yaitu: item no 15, 16, 17, 18. Nilai rata-rata pada item no 15 dihasilkan dari $(30 \times 4)+(9 \times 3)+(1 \times 2)=120+27+2=$ $149: 40=3,72$. Nilai rata-rata pada item no 16 dihasilkan dari $(9 \times 4)+(20 \times 3)+(9 \times 2)+$ $(2 \times 1)=36+60+18+2=116: 40=2,9$. Nilai rata-rata pada item no 17 dihasilkan dari $(28 \times 4)+(9 x 3)+(3 \times 2)=112+27+6=145: 40=3,62$. Nilai rata-rata pada item no 18 dihasilkan dari $(4 \times 4)+(12 \times 3)+(18 \times 2)+(6 \times 1)=16+36+36+6=94: 40=2,35$. 
Dari data tersebut, apabila kelima skor rata-rata setiap item tersebut dihitung ratarata akhirnya, maka hasilnya adalah $(3,72+2,9+3,62+2,35): 4=12,59: 4=3,15$. Dengan demikian, indikator dimensi pengalaman kualitas keberagamaan orang tua termasuk ke dalam kategori cukup, karena berada pada interval 2,5 - 3,5.

e) Dimensi pengetahuan

Untuk mendalami indikator ini, penulis mengajukan 6 pertanyaan yaitu item no $19,20,21,22,23,24$. Nilai rata-rata pada item no 19 adalah $39: 40$ x $100=97,5$ nilai tersebut berada pada rentang 90 - 100, maka termasuk ke dalam kategori amat baik. Item no 20 nilai rata-ratanya adalah $38: 40 \times 100=95$ nilai tersebut berada pada rentang 90 - 100, maka termasuk ke dalam kategori amat baik. Item no 21 nilai rata-ratanya adalah $20: 40 \times 100=50$ nilai tersebut berada pada rentang $50-59$, maka termasuk ke dalam kategori kurang. Item no 22 nilai rata-ratanya adalah $39: 40$ x $100=97,5$ nilai tersebut berada pada rentang 90 - 100, maka termasuk ke dalam kategori amat baik. Item no 23 nilai rata-ratanya adalah $38: 40$ x $100=95$ nilai tersebut berada pada rentang 90 - 100, maka termasuk ke dalam kategori amat baik. Item no 24 nilai rata-ratanya adalah $26: 40 \times 100=65$ nilai tersebut berada pada rentang $60-69$, maka termasuk ke dalam kategori sedang.

Nilai rata-rata dari keseluruhan data diatas adalah $(97,5+95+50+97,5+95+$ $65): 6=500: 6=83,33$. Nilai tersebut berada pada rentang $80-90$.

Beradasarkan keseluruhan data yang diperoleh dari setiap indikator variabel $\mathrm{X}$, terkecuali dimensi pengetahuan, maka dapat diketahui hasil rata-ratanya yaitu $(3,76+$ $3,61+3,28+3,15): 4=13,8: 4=3,45$.

2. Analisis Seluruh Variabel $X$

a. Tendensi Sentral

Berdasarkan hasil penghitungan tendensi sentral empat indikator dari variabel X, diketahui Mean sebesar 62,6, Median sebesar 19,96, dan Modus sebesar -65,32. Sedangkan tendensi sentral indikator pengetahuan variabel $\mathrm{X}$ diketahui Mean sebesar 83,25, Median sebesar 30,15, dan Modus sebesar -76,05.

\section{b. Uji Normalitas}

Berdasarkan hasil perhitungan, uji normalitas empat indikator pada variabel $\mathrm{X}$ yang berupa angket berdistribusi normal dengan harga $x^{2}$ hitung $(2,74)<x^{2}$ tabel $(9,488)$. Sedangkan hasil uji normalitas dari indikator pengetahuan yang berupa soal pilihan ganda berdistribusi tidak normal dengan harga $x^{2}$ hitung $(19,3)>x^{2}$ tabel $(9,488)$.

Selanjutnya mengenai Motivasi Belajar Siswa

1. Analisis Parsial Perindikator Variabel Y

a. Adanya hasrat dan keinginan berhasil

Pada indikator ini mengajukan 5 item pertanyaan yaitu: item 1, 2, 3, 4, 5. Item no 1 diperoleh angka rata-ratanya dari $(5 \times 4)+(24 x 3)+(11 \times 2)=20+72+22=114$ : $40=2,85$. Angka tersebut termasuk ke dalam kategori cukup, karena berada pada interval $2,5-3,5$. Item no 2 diperoleh angka rata-ratanya, yaitu $(12 \times 4)+(17 \times 3)+(11 \times 2)$ 
$=48+51+22=121: 40=3,02$. Angka tersebut termasuk ke dalam kategori cukup, karena berada pada interval 2,5-3,5. Item no 3 diperoleh angka rata-ratanya, yaitu $(6 \times 3)$ $+(29 \times 2)+(5 \times 1)=18+58+5=81: 40=2,02$. Angka tersebut termasuk ke dalam kategori negatif, karena berada pada interval $1,5-2,5$. Item no 4 diperoleh angka rataratanya, yaitu $(2 \times 4)+(5 \times 3)+(29 \times 2)+(4 \times 1)=8+15+58+4=85: 40=2,12$. Angka tersebut termasuk ke dalam kategori kurang, karena berada pada interval 1,5 $-2,5$. Item no 5 diperoleh angka rata-ratanya, yaitu $(13 \times 4)+(12 \times 3)+(14 \times 2)+(1 \times 1)=52+36+$ $28+1=117: 40=2,92$. Angka tersebut termasuk ke dalam kategori cukup, karena berada pada interval 2,5-3,5. Kelima skor rata-rata tersebut dihitung rata-rata akhirnya, maka hasilnya adalah $(2,85+3,02+2,02+2,12+2,92): 5=12,93: 5=2,58$. Dengan demikian, indikator adanya hasrat dan keinginan berhasil termasuk ke dalam kategori cukup, karena berada pada interval 2,5 - 3,5.

b. Adanya dorongan dan kebutuhan dalam belajar

Pada indiktaor ini mengajukan 5 item pertanyaan yaitu: $6,7,8,9$, 10. Item no 6 diperoleh angka rata-ratanya, yaitu dari $(1 \times 4)+(12 \times 3)+(25 \times 2)+(2 \times 1)=4+36+50$ $+2=92: 40=2,3$. Angka tersebut termasuk ke dalam kategori kurang, karena berada pada interval $1,5-2,5$. Item no 7 diperoleh angka rata-ratanya, yaitu dari $(16 \times 4)+$ $(17 \times 3)+(6 \times 2)+(1 \times 1)=64+51+12+1=128: 40=3,2$. Angka tersebut termasuk ke dalam kategori cukup, karena berada pada interval $2,5-3,5$. Item no 8 diperoleh angka rata-ratanya, yaitu dari $(5 \times 4)+(13 \times 3)+(21 \times 2)+(1 \times 1)=20+39+42+1=102: 40=$ 2,55 . Angka tersebut termasuk ke dalam kategori cukup, karena berada pada interval 2,5 $-3,5$. Item no 9 diperoleh angka rata-ratanya, yaitu dari $(7 \times 4)+(19 \times 3)+(14 \times 2)=28+$ $57+28=113: 40=2,82$. Angka tersebut termasuk ke dalam kategori cukup, karena berada pada interval $2,5-3,5$. Item no 10 diperoleh angka rata-ratanya, yaitu dari $(5 \times 4)$ $+(14 \times 3)+(21 \times 2)=20+42+42=104: 40=2,6$. Angka tersebut termasuk ke dalam kategori cukup, karena berada pada interval 2,5 - 3,5.

Dari data tersebut, apabila kelima skor rata-rata setiap tersebut dihitung rata-rata akhirnya, maka hasilnya adalah $(2,3+3,2+2,55+2,82+2,6): 5=13,47: 5=2,69$. Dengan demikian, indikator adanya dorongan dan kebutuhan dalam belajar termasuk ke dalam kategori cukup, karena berada pada interval 2,5 - 3,5.

c. Adanya harapan dan cita-cita masa depan

Pada indikator ini mengajukan 3 item pertanyaan yaitu: 11, 12, 13. Item no 11 diperoleh angka rata-ratanya yaitu dari $(9 \times 4)+(25 \times 3)+(6 \times 2)=36+75+12=123: 40$ $=3,07$. Angka tersebut termasuk ke dalam kategori cukup, karena berada pada interval $2,5-3,5$. Item no 12 diperoleh angka rata-ratanya yaitu dari $(9 \times 4)+(26 \times 3)+(5 \times 2)=$ $36+78+10=124: 40=3,1$. Angka tersebut termasuk ke dalam kategori cukup, karena berada pada interval $2,5-3,5$. Item no 13 diperoleh angka rata-ratanya yaitu dari $(5 \times 4)$ $+(14 \times 3)+(21 \times 2)+(1 \times 1)=20+42+42=104: 40=2,6$. Angka tersebut termasuk ke dalam kategori cukup, karena berada pada interval 2,5 -3,5.

Dari data tersebut, apabila ketiga skor rata-rata tersebut dihitung rata-rata akhirnya, maka hasilnya adalah $(3,07+3,1+2,6): 3=8,77: 3=2,92$. Dengan demikian, 
indikator adanya harapan dan cita-cita masa depan termasuk ke dalam kategori cukup, karena berada pada interval 2,5 - 3,5.

d. Adanya penghargaan dalam belajar

Pada indikator ini mengajukan 3 item pertanyaan yaitu: 14, 15, 16. Item no 14 diperoleh angka rata-ratanya yaitu dari $(10 \times 4)+(8 \times 3)+(15 \times 2)+(7 \times 1)=40+24+30$ $+7=101: 40=2,52$. Angka tersebut termasuk ke dalam kategori cukup, karena berada pada interval $2,5-3,5$. Item no 15 diperoleh angka rata-ratanya yaitu dari $(19 x 4)+$ $(14 \times 3)+(7 \times 2)=76+42+14=132: 40=3,3$. Angka tersebut termasuk ke dalam kategori cukup, karena berada pada interval 2,5 - 3,5. Item no 16 diperoleh angka rataratanya yaitu dari $(2 \times 4)+(6 \times 3)+(26 \times 2)+(6 \times 1)=8+18+52+6=84: 40=2,1$. Angka tersebut termasuk ke dalam kategori kurang, karena berada pada interval 1,5 2,5 .

Dari data tersebut, apabila ketiga skor rata-rata tersebut dihitung rata-rata akhirnya, maka hasilnya adalah $(2,52+3,3+2,1): 3=7,92: 3=2,64$. Dengan demikian, indikator adanya penghargaan dalam belajar termasuk ke dalam kategori cukup, karena berada pada interval $2,5-3,5$.

e. Adanya kegiatan yang menarik dalam belajar

Pada indikator ini mengajukan 4 item pertanyaan yaitu: 17, 18, 19, 20. Item no 17 diperoleh angka rata-ratanya yaitu dari $(1 \times 4)+(2 \times 3)+(22 \times 2)+(15 \times 1)=4+6+44$ $+15=69: 40=1,72$. Angka tersebut termasuk ke dalam kategori kurang, karena berada pada interval $1,5-2,5$. Item no 18 diperoleh angka rata-ratanya yaitu dari $(28 \times 4)+$ $(10 \times 3)+(2 \times 2)=112+30+4=146: 40=3,65$. Angka tersebut termasuk ke dalam kategori baik, karena berada pada interval 3,5-4,5. Item no 19 diperoleh angka rataratanya yaitu dari $(9 \times 4)+(19 \times 3)+(10 \times 2)+(2 \times 1)=36+57+20+2=115: 40=2,87$. Angka tersebut termasuk ke dalam kategori cukup, karena berada pada interval $2,5-$ 3,5 . Item no 20 diperoleh angka rata-ratanya yaitu dari $(16 \times 4)+(10 \times 3)+(14 \times 2)=64+$ $30+28=122: 40=3,05$. Angka tersebut termasuk ke dalam kategori cukup, karena berada pada interval $2,5-3,5$.

Dari data tersebut, apabila ketiga skor rata-rata setiap item tersebut dihitung ratarata akhirnya, maka hasilnya adalah $(1,72+3,65+2,87+3,05): 4=11,29: 4=2,82$. Dengan demikian, indikator adanya kegiatan yang menarik dalam belajar termasuk ke dalam kategori cukup, karena berada pada interval 2,5 - 3,5.

f. Adanya lingkungan belajar yang kondusif

Pada indikator ini mengajukan 3 item pertanyaan yaitu: 21, 22, 23. Item no 21 diperoleh angka rata-ratanya yaitu dari $(3 \times 3)+(19 \times 2)+(18 \times 1)=9+38+18=65: 40$ $=1,62$. Angka tersebut termasuk ke dalam kategori kurang, karena berada pada interval $1,5-2,5$. Item no 22 diperoleh angka rata-ratanya yaitu dari $(7 \times 4)+(12 \times 3)+(15 \times 2)+$ $(6 \times 1)=28+36+30+6=100: 40=2,5$. Angka tersebut termasuk ke dalam kategori cukup, karena berada pada interval $2,5-3,5$. Item no 23 diperoleh angka rata-ratanya yaitu dari $(22 \times 4)+(12 \times 3)+(5 \times 2)+(1 \times 1)=88+36+10+1=135: 40=3,37$. Angka tersebut termasuk ke dalam kategori cukup, karena berada pada interval 2,5 -3,5. 
Dari data tersebut, apabila ketiga skor rata-rata item tersebut dihitung rata-rata akhirnya, maka hasilnya adalah $(1,62+2,5+3,37): 3=7,49: 3=2,49$. Dengan demikian, indikator adanya lingkungan belajar yang kondusif termasuk ke dalam kategori cukup, karena berada pada interval 2,5 - 3,5.

2. Analisis Seluruh Variabel Y

a. Tendensi Sentral

Berdasarkan hasil penghitungan tendensi sentral variabel $\mathrm{Y}$, diketahui Mean sebesar 62, Median sebesar 19,96 dan Modus sebesar -64,12.

b. Uji Normalitas

Berdasarkan hasil perhitungan, uji normalitas empat indikator pada variabel $\mathrm{Y}$ yang berupa angket berdistribusi normal dengan harga $x^{2}$ hitung $(4,19)<x^{2}$ tabel $(9,488)$.

Untuk mengetahui pengaruh kualitas keberagamaan orang tua terhadap motivasi belajar PAI siswa, yaitu dengan melakukan uji linearitas regresi dan uji korelasional.

c. Hasil Uji Linearitas Regresi

1) Penghitungan antara variabel $X$ yang berupa angket dan variabel $Y$ termasuk regresi linear, maka untuk menghitungnya menggunakan pendekatan product moment. Hasil yang diperoleh koefisien sebesar 0,15 . membuktikan bahwa derajat pengaruh antara variabel $\mathrm{X}$ dan variabel $\mathrm{Y}$ dari hasil perhitungan (terlampir).

2) Penghitungan antara indikator pengetahuan variabel $X$ yang berupa soal pilihan ganda dengan variabel $\mathrm{Y}$, penghitungan menggunakan koefisien korelasi rank karena salah satu tidak normal. Hasil yang diperoleh koefisien korelasi rank sebesar 0,23.

Kedua hasil koefisien korelasi tersebut di jumlahkan manjadi 0,15 0,23 =0,38. Penjumlahan dari kedua hasil yang diperoleh tersebut membuktikan bahwa derajat pengaruh antara variabel $\mathrm{X}$ dan variabel $\mathrm{Y}$ sebesar 0,38 .

d. Uji Hipotesis

Dari perhitungan penjumlahan hipotesis hasil $t_{\text {hitung(1) }} 0,93+t_{\text {hitung(2) }} 1,54=2,47$ dan $t_{\text {tabel }}$ sebesar 2,024 dengan taraf signifikasi 5\%, sehingga $t_{\text {hitung }}>t_{\text {tabel }}$. Hal ini berarti bahwa hipotesis nol (Ho) yang menyatakan tidak terdapatnya pengaruh antara kedua variabel tersebut di tolak, yang menyatakan tidak terdapat pengaruh anatara kualitas keberagamaan orang tua terhadap motivasi belajar Pendidikan Agama Islam pada siswa diterima. Sedangkan hipotesis alternatif $(\mathrm{Ha})$ yang menyatakan terdapat pengaruh antara kedua variabel tersebut di terima.

e. Uji Pengaruh Variabel X terhadap Variabel Y

Untuk mengetahui ada atau tidak adanya pengaruh variabel $\mathrm{X}$ terhadap variabel Y diperoleh angka derajat adanya korelasi sebesar $8 \%$ jadi menurut hasil penelitian, ada $8 \%$ kualitas kebergamaan orang tua yang mempengaruhi motivasi belajar PAI siswa. Angka ini menunjukkan bahwa masih banyak faktor lain yaitu sebesar 92\% yang turut mempengaruhi motivasi belajar Pendidikan Agama Islam pada siswa. 


\section{SIMPULAN}

Berdasarkan hasil analisis dan pembahasan dari penelitian ini diperoleh kesimpulan bahwasannya, realitas kualitas keberagamaan orang tua termasuk dalam kategori cukup. Cukup artinya sebagian besar orang tua siswa sudah memiliki kualitas keberagamaan (religiusitas) dalam kategori cukupl pada setiap dimensi-dimensi religiusitas. Hal ini ditunjukkan oleh nilai rata-rata seluruh indikator variabel $\mathrm{X}$ sebesar 3,45 dengan skala $2,5-3,5$. Sedangkan untuk indikator dimensi pengetahuan juga dapat dikategorikan baik karena diperoleh nilai sebesar 83,33 yang mana angka tersebut berada pada interval 80 - 89. Mengenai motivasi belajar pendidikan Agama Islam siswa kelas X MAN 1 Majalengka dikatgeorikan cukup, artinya subjek sudah memiliki aspek yang dapat memotivasi siswa dalam belajar, namun masih ada beberapa aspek yang belum terpenuhi dengan baik. Hal ini di tunjukkan oleh nilai rata-rata seluruh indikator variabel Y sebesar 2,69 yang berada pada interval 2,5 - 3,5. Pengaruh kualitas keberagamaan orang tua terhadap motivasi belajar pendidikan Agama Islam pada siswa kelas X MAN 1 Majalengka, ternyata menghasilkan angka korelasi sebesar 0,38 yang jika di kualifikasikan termasuk pada kategori rendah, karena berada pada skala 0,200-0,399. Dan dilihat dari tinggi rendahnya kadar pengaruh kualitas keberagamaan orang tua terhadap motivasi belajar Pendidikan Agama Islam siswa mencapai 8\%, artinya keberagamaan orang tua memiliki pengaruh sebesar $8 \%$ terhadap motivasi belajar Pendidikan Agama Islam pada siswa.

\section{DAFTAR PUSTAKA}

Daradjat, Z. (2008). Ilmu Pendidikan Islam. Jakarta: Bumi Aksara.

Didiek Ahmad Supadie, d. (2012). Pengantar Studi Islam. Jakarta: PT RajaGrafindo Persada.

Djamaludin Ancok, F. N. (2011). Psikologi Islami. Yogyakarta: Pustaka Pelajar.

Eveline Siregar, H. N. (2014). Teori Belajar dan Pembelajaran. Bogor: Ghalia Indonesia.

Gunawan, H. (2012). Kurikulum dan Pembelajaran Pendidikan Agama Islam. Bandung: Alfabeta.

Jalaludin. (2012). Psikologi Agama. Jakarta: PT. Raja Grafindo Persada.

M. Nur Ghufron, R. R. (2012). Teori-Teori Psikologi. Jogjakarta: Ar-Ruzz Media.

Mahmud, H. G. (2012). Pendidikan Agama Islam dalam Keluarga. Jakarta: Penerbit Akademia.

Subandi, M. (2013). Psikologi Agama \& Kesehatan Mental. Yogyakarta: Pustaka Pelajar.

Uno, H. B. (2016). Teori Motivasi dan Pengukurannya. Jakarta: Bumi Aksara.

Zainuddin, A. (2017, Agustus 30). pengertian-keberagamaan. Dipetik Maret 10, 2018, dari pengertiankomplit.blogspot.co.id:

http://pengertiankomplit.blogspot.co.id/2017/08/pengertian-keberagamaan.html 